\title{
Effect of nitrogen nutrition on growth and nitrate accumulation in lettuce (Lactuca sativa L.), under various conditions of radiation and temperature
}

\author{
Laurent DAPOIGnY ${ }^{\mathrm{a}}$, Stéphane de TouRdonnet ${ }^{\mathrm{b} *}$, Jean Roger-ESTRADE $^{\mathrm{b}}$, \\ Marie-Hélène JeUFFrOY ${ }^{\mathrm{b}}$, André FLEURY ${ }^{\mathrm{c}}$ \\ ${ }^{a}$ Chaire des Sciences et Techniques des Productions Légumières, ENSH, 2 rue Le Nôtre, 49005 Angers, France \\ ${ }^{\mathrm{b}}$ Laboratoire d'agronomie INRA-INAPG, BP 01, 78850 Thiverval-Grignon, France \\ ${ }^{\mathrm{c}}$ Laboratoire d'agriculture périurbaine, ENSP, 4 rue Hardy, RP 914, 78009 Versailles, France
}

(Received 9 August 1999; revised 17 February 2000; accepted 11 May 2000)

\begin{abstract}
A better understanding of the effect of environmental factors on growth and nitrate accumulation in plants is necessary to develop cultivation practices, and in particular for providing lettuces with a low nitrate content. This study was conducted to analyse the effect of nitrogen supply on the interception and conversion of the PAR in dry matter, and on the nitrate and water accumulations in fresh tissues of the lettuce, for various conditions of temperature and radiation. The growth, and water and nitrate concentrations of two soilless cultures of lettuce (summer and autumn) were measured for two levels of radiation and two levels of nitrogen supply. RUE ranged from 2.12 to $3.50 \mathrm{~g} \cdot \mathrm{MJ}^{-1}$, being higher for a low radiation level and for a high nitrogen supply. There was a positive correlation between the lettuce nitrate and water contents. The slope of this relationship was not affected by environmental conditions, indicating a strong interdependance between nitrate and water accumulation in lettuce.
\end{abstract}

radiation use efficiency / RUE / nitrate / water / shading / sand culture / drip irrigation / greenhouse

Résumé - Effet de la nutrition azotée sur la croissance et l'accumulation du nitrate chez la laitue (Lactuca sativa L.), sous des conditions variées de rayonnement et de température. Pour concevoir des itinéraires techniques permettant d'obtenir une faible teneur en nitrate des laitues, il est nécessaire de mieux comprendre les effets des conditions de culture sur la croissance et l'accumulation de nitrate dans la plante. L'objectif de cette étude est d'analyser l'effet de la nutrition azotée sur l'efficience d'interception et de conversion du rayonnement en matière sèche, et sur l'accumulation de nitrate et d'eau dans la laitue, pour différentes conditions de température et de rayonnement. La croissance des laitues et les concentrations en eau et en nitrate ont été mesurées sur deux cultures hors-sol (en été et en automne) avec deux niveaux de rayonnement incident et de nutrition azotée. L'efficience de conversion de l'énergie lumineuse en

Communicated by Gérard Guyot (Avignon, France)

* Correspondence and reprints

tourdonn@ inapg.inra.fr 
matière sèche (RUE) était comprise entre 2.12 et $3.5 \mathrm{~g} \cdot \mathrm{MJ}^{-1}$. Elle était plus élevée pour les faibles rayonnements et les forts niveaux de nutrition azotée. Une corrélation positive entre les teneurs en nitrate et en eau a été observée. Cette relation, dont la pente n'est pas affectée par les conditions de croissance, semblerait indiquer une forte interdépendance des accumulations d'eau et de nitrate chez la laitue.

efficience d'utilisation du rayonnement / nitrate / eau / ombrage / culture en pot / irrigation au goutte à goutte / serre

\section{Introduction}

Lettuce consumption may cause important nitrate inputs in the human diet. This explains why a maximum admissible nitrate content in lettuce heads has been fixed in European countries since 1997. Thus, a better understanding of the effects of environmental factors on nitrate accumulation in lettuce leaves is essential for crop management leading to an acceptable production.

Studies on nitrate accumulation in lettuce have shown that solar radiation and nitrogen supply are the major factors that influence the nitrate content of fresh matter [17, 19, 33, 41]. Radiation is believed to act through an enhancement of nitrate reductase activity thus increasing nitrate assimilation and thereby decreasing nitrate content of plants [26]. The role of nitrate in regulating the osmotic pressure of plant tissues has also been emphasised. Over the past decade, several studies have shown that nitrate concentration in lettuce is negatively correlated with the content of soluble carbohydrates $[5,28]$. Thus, lower nitrate concentrations in lettuce are observed when the concentration of carbohydrates increases, which is associated with the stimulation of photosynthesis by higher light levels. This effect has been ascribed to the complementary actions of nitrate and soluble sugars in maintaining cell turgor [42].

Nitrogen supply affects both nitrate accumulation and plant growth $[3,32,44]$. Growth depends on the efficiency of radiation interception and on the efficiency with which this radiation is transformed into biomass, i.e. the Radiation Use Efficiency (RUE) [18, 43]. The interception efficiency is usually estimated from the cover rate of the crop for lettuce $[8,15,22,45]$. The RUE is defined by the slope of the linear relationship between biomass accumulation and Photosynthetically Active Radiation (PAR) intercepted by the canopy. This efficiency varies according to environmental factors, mainly temperature and radiation $[10,22,38,46]$. Interception efficiency and RUE also depend on the nitrogen supply, because a shortage of this element decreases the growth of the leaves [25] and the photosynthetic capacity of the plant $[6,16,37]$. No study on the effects of nitrogen supply and radiation level on RUE has yet been reported for lettuce during its entire growth cycle.

We have therefore analysed the effects of nitrogen supply and radiation on the interception and conversion of PAR in dry matter, and on nitrate and water accumulations in fresh tissues of lettuce during two growing periods: summer and autumn.

\section{Materials and methods}

This experiment has already been partially described in Agronomie [13, 14].

\subsection{Plant growth conditions}

The experiment was carried out on two crops, under contrasting conditions of radiation and temperature. One was grown in summer and the other in autumn. Seedlings of lettuce (Lactuca sativa L., cv. Judy) at the 4-5 leaves stage were planted out in a plastic greenhouse, in pots (3 1) filled with sand (granulometry: $0.8-1.8 \mathrm{~mm}$ ). Plantation density was 12.6 plants $\cdot \mathrm{m}^{-2}$. Water and mineral nutrition were delivered by a drip system controlled by an automatic station (Indal, Industrieweg 30, 
Holland BV). The supply of the nutrient solution was set at $50 \mathrm{ml}$ per plant for every $0.2 \mathrm{~mm}$ of potential evapotranspiration for all the treatments, with continuous drainage of $60 \%$ of the volume supplied. The plastic cover of the greenhouse was whitened in summer, to prevent high temperatures from inhibiting plant growth.

\subsection{Treatments}

The range of radiation levels investigated was extended by including a low radiation treatment both in summer and autumn. We shaded the canopy in each of the crops so that the shaded plants received $60 \%$ of the radiation received by the non-shaded ones (R2 refers to the natural radiation treatments, and R1 to the shaded ones). Two concentrations of nitrogen were supplied in the nutrient solution: N2 (high) and N1 (low). Nutrient solution $\mathrm{N} 2$ ensured non-limiting nutrition $\left(\mathrm{mmol}^{-1}: \quad 1.55 \mathrm{Ca}(\mathrm{NO} 3)_{2}, \quad 2.05 \quad \mathrm{KNO}_{3}\right.$,

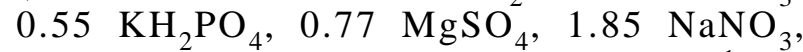
$0.99 \mathrm{NaCl}$ ). Its conductivity was $960 \mu \mathrm{S} \cdot \mathrm{cm}^{-1}$ and the nitrate concentration was $7 \mathrm{mmol} \cdot \mathrm{l}^{-1}$. Nutrient solution $\mathrm{N} 1$ was obtained by diluting $\mathrm{N} 2$ solution to a nitrate content of $3 \mathrm{mmol} \cdot \mathrm{l}^{-1}$; the conductivity was $460 \mu \mathrm{S} \cdot \mathrm{cm}^{-1}$. Micro-elements were added to the diluted $\mathrm{N} 1$ solution. Thus the micro-element contents in $\mathrm{N} 1$ and $\mathrm{N} 2$ were the same $\left(\mu \mathrm{mol} \cdot \mathrm{l}^{-1}\right.$ : 15.76 Fe-EDTA, 23.46 Mn, 8.57 Zn, $0.8 \mathrm{Cu}$, $63.64 \mathrm{~B}, 0.52 \mathrm{Mo}$ ). The $\mathrm{pH}$ of this solution was 5.7-6.1. Nitrate represented $70 \%$ of the anionic charge in the two nutrient solutions. The four treatments (R2N2, R2N1, R1N2, R1N1) were applied to each crop from planting to harvest. The summer crop was planted out on August 2nd 1994 and harvested on September 6th 1994. The autumn crop was planted out on October 12th 1994 and harvested on December 22nd 1994 (R2) and on January 3rd 1995 (R1).

\subsection{Experimental design and plant measurements}

The same experimental design was used in summer and in autumn. The four treatments were arranged in a split-plot design in the greenhouse, with two replications. A total of twelve samples were taken from each plot between planting and harvest to monitor biomass and nitrate accumulation during the crop cycle. The interval between sampling dates was 2-7 days, depending on crop development. Each sample consisted of four neighbouring lettuce heads harvested at dawn to ensure the same state of hydration. Plant density was maintained by moving the pots. The four adjacent lettuce heads were photographed from above before sampling, to measure the proportion of soil surface covered by the canopy. Measurements were taken by image analysis of the pictures. The aerial parts of each plant were weighted before and after oven drying $\left(48 \mathrm{~h}, 80{ }^{\circ} \mathrm{C}\right)$. The nitrogen content of the crushed dried aerial parts of each sample was analysed by the Dumas method which takes into account the total nitrogen in the plant, including the nitrate. Nitrate was extracted in water and analysed by ion chromatography (Dionex Dx 300, USA).

\subsection{Climatic data}

Temperature and incoming radiation were recorded using a datalogger (CR10, Campbell Scientific). Measurements were recorded every six minutes. Mean daily values are the average of the 240 values obtained every day. The air temperature above plants was measured with a platinum probe (PT100) protected from radiation. The incident photosynthetically active radiation (PAR) was measured with four gallium arsenic photodiodes [29] placed $0.1 \mathrm{~m}$ above the canopy, one for each treatment. No differences were observed between the two photodiodes measuring natural radiation (R2) and between the two ones measuring low radiation (R1). The intercepted PAR was computed by multiplying incident PAR by an interception coefficient, which depended on the cover rate of the canopy [15]. The radiation and temperature during the two crop cycles are shown in Figure 1. Shading did not change air temperature. 

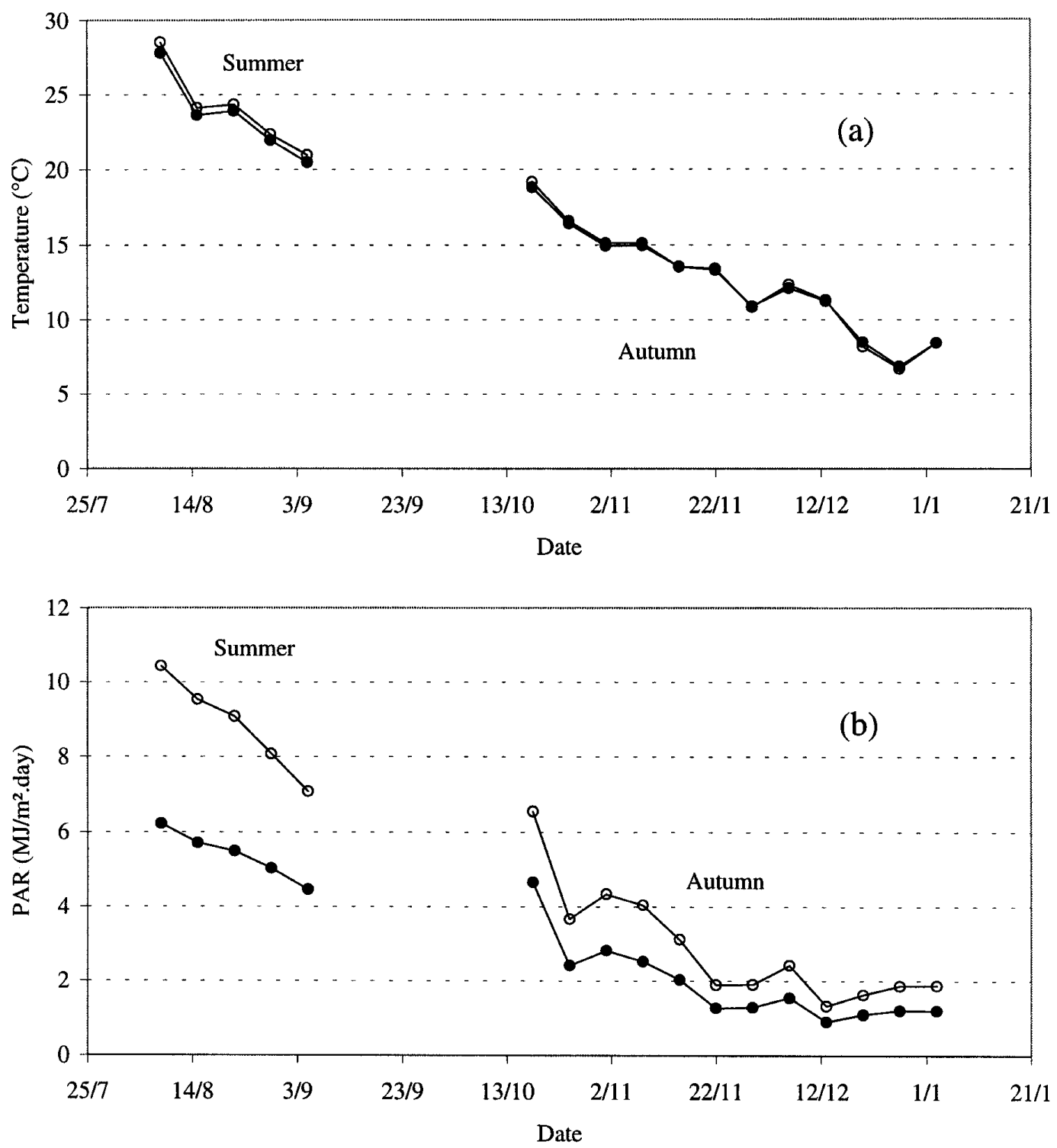

Figure 1. Weekly mean of greenhouse air temperature (a) and photosynthetic active radiation (PAR) (b) during growth of the two lettuce crops in summer and autumn: natural radiation (R2, open symbols) and shaded conditions (R1, closed symbols).

\subsection{Statistical analysis}

Linear regressions were performed using the REG procedure of SAS [34]. The slopes were compared by covariance analysis, using the General Linear Model procedure of SAS.

\section{Results}

\subsection{Cover rate}

Cover rate, expressed as a function of thermal time (basal temperature: $3{ }^{\circ} \mathrm{C}[13,35,36]$ ) 
increased in a sigmoid fashion (Fig. 2). A plateau was reached $500{ }^{\circ} \mathrm{C} \cdot \mathrm{d}$ after planting, although there was a slight increase in the cover rate after this date, mainly at the high radiation level (R2). This date corresponded to the beginning of the heading of the lettuces in summer and in autumn. The cover rate was higher for the R1 than for the R2 treatments under a given level of mineral nutrition. A shortage of nitrogen supply reduced the cover rate at a given radiation level, both in autumn and summer.

\subsection{Dry matter accumulation}

The relationship between the cumulative PAR intercepted by the plants and the dry matter
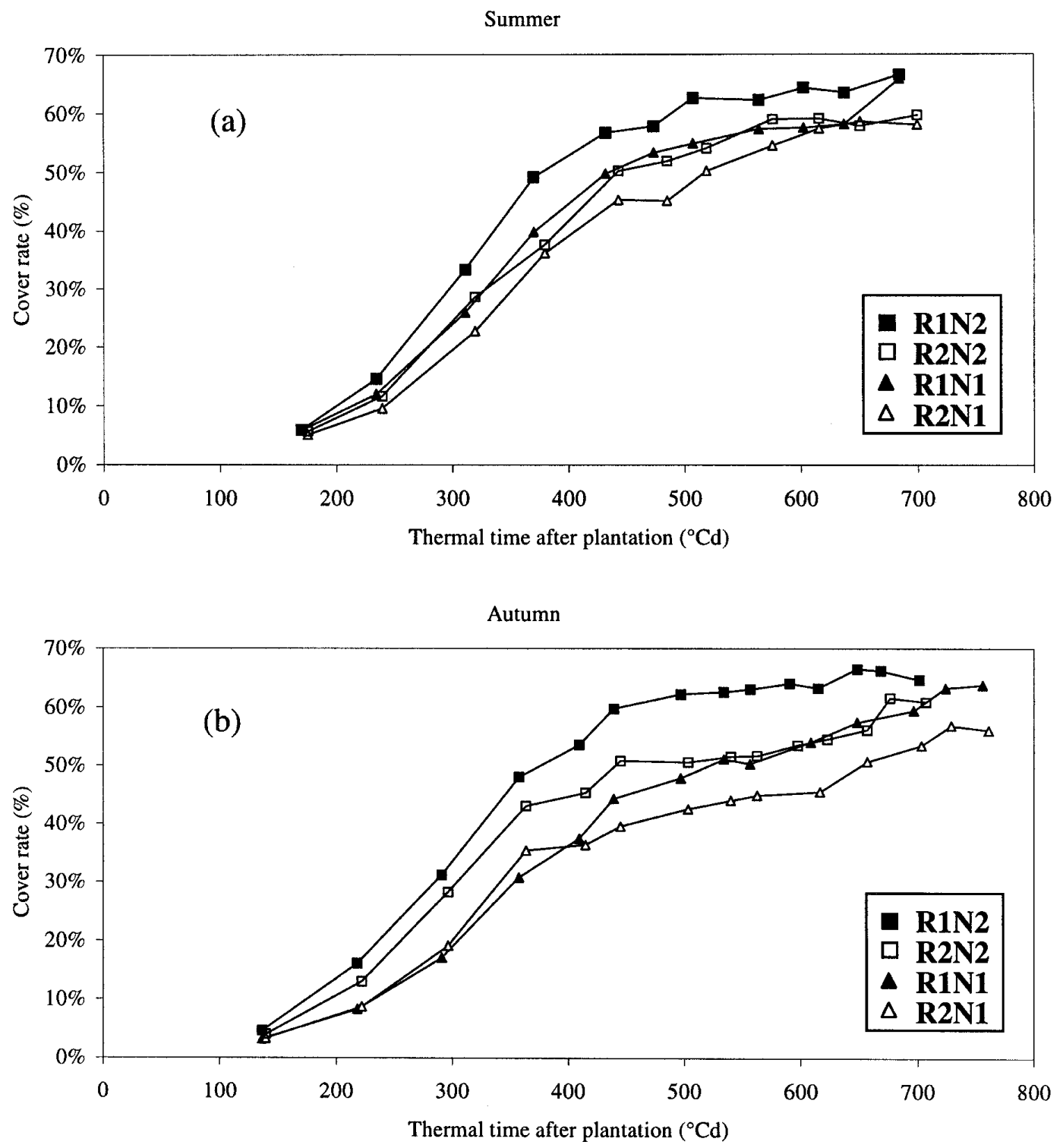

Figure 2. Changes in the cover rate of lettuce with thermal time in summer (a) and in autumn (b). Crops received high (N2) or low (N1) nitrogen inputs and natural (R2) or low (R1) radiations (shading). 

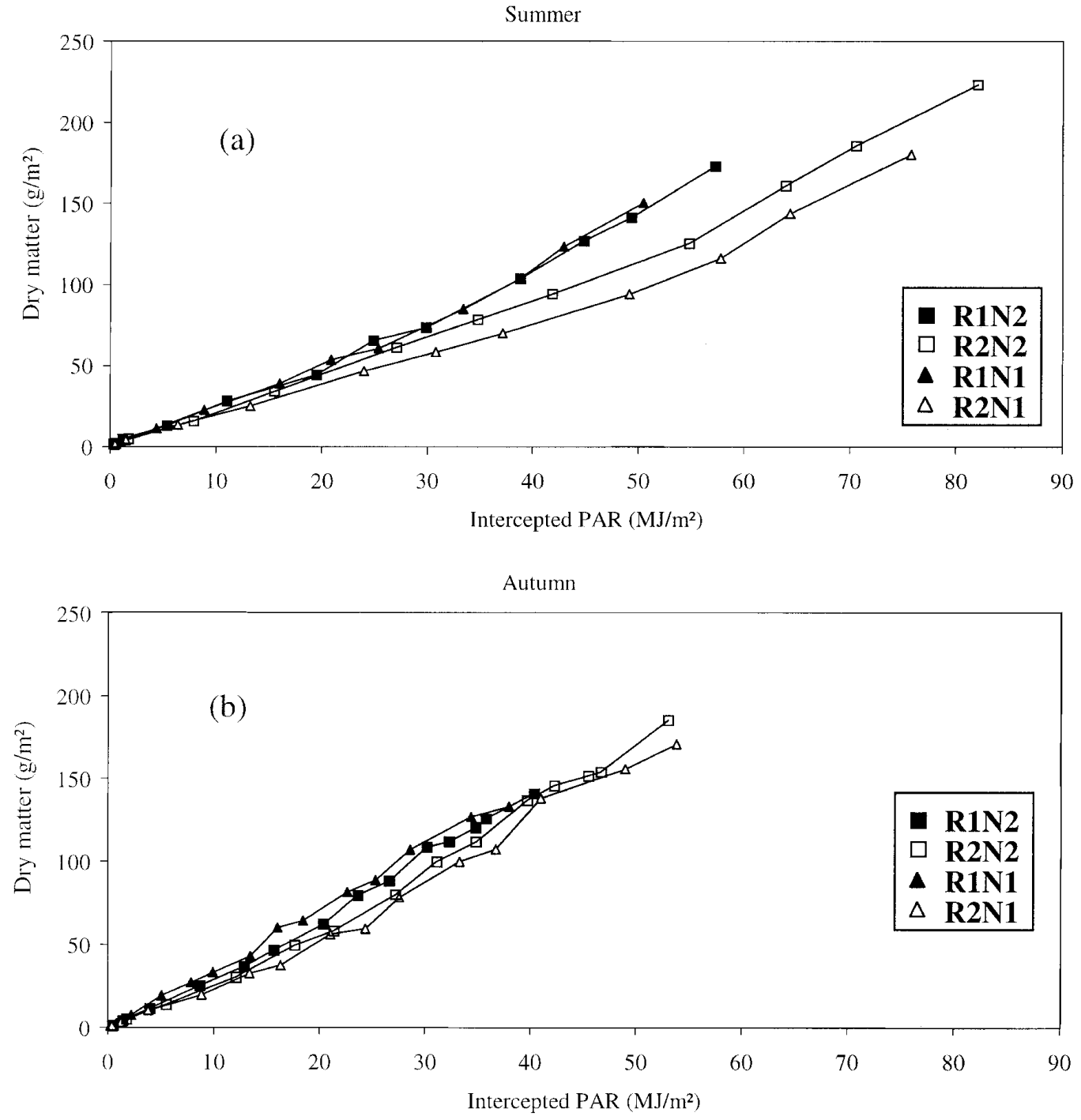

Figure 3. Dry matter accumulation of lettuce as a function of the calculated cumulated PAR intercepted in summer (a) and autumn (b).

Table I. RUE for dry matter accumulation $\left(\mathrm{g} \cdot \mathrm{MJ}^{-1}\right)$ and correlation coefficient $\left(r^{2}\right)$ of summer and autumn crops, grown under natural (R2) or low (R1) radiation, and with high (N2) or low (N1) nitrogen inputs.

\begin{tabular}{|c|c|c|c|c|c|c|}
\hline & \multicolumn{3}{|c|}{ Summer } & \multicolumn{3}{|c|}{ Autumn } \\
\hline & $\mathrm{R} 1$ & $\mathrm{R} 2$ & $\mathrm{R}$ effect $\mathrm{t}^{\S}$ & $\mathrm{R} 1$ & $\mathrm{R} 2$ & $\mathrm{R}$ effect $\mathrm{t}^{\S}$ \\
\hline N1 & $\begin{array}{c}2.72 \\
r^{2}=0.986\end{array}$ & $\begin{array}{c}2.12 \\
r^{2}=0.979\end{array}$ & $* * *$ & $\begin{array}{c}3.34 \\
r^{2}=0.996\end{array}$ & $\begin{array}{c}2.97 \\
r^{2}=0.986\end{array}$ & $* * *$ \\
\hline $\mathrm{N} 2$ & $\begin{array}{c}2.77 \\
r^{2}=0.987\end{array}$ & $\begin{array}{c}2.49 \\
r^{2}=0.986\end{array}$ & $* *$ & $\begin{array}{c}3.50 \\
r^{2}=0.992\end{array}$ & $\begin{array}{c}3.21 \\
r^{2}=0.991\end{array}$ & $* *$ \\
\hline $\mathrm{N}$ effect ${ }^{\S}$ & NS & $* *$ & & $* *$ & $*$ & \\
\hline
\end{tabular}

$\S: *, * * * * *=$ significant at the $0.05,0.01$ and 0.001 levels; $\mathrm{NS}=$ not significant. 
accumulation was linear, with a better fit in autumn than in summer (Fig. 3). The slope increased slightly at the end of the crop cycle in summer. The mean values of RUE for dry matter accumulation, calculated as the slopes of the regression line, varied between 2.12 and $2.77 \mathrm{~g} \cdot \mathrm{MJ}^{-1}$ (Tab. I). Values were higher in autumn and varied between 2.97 and $3.50 \mathrm{~g} \cdot \mathrm{MJ}^{-1}$. Covariance analysis showed a significant effect of radiation for a given level of mineral nutrition; the RUE was lower for R2 than for R1 plants. RUE was higher for N2 than for N1 plants at a given radiation level, except for the low radiation (R1) in summer, where the difference between the N1 and N2 crops was not significant.

Total nitrogen content remained lower in N1 than in N2 plants during all the experiment, as shown by Dapoigny et al. ([14], Fig. 3), indicating that a nitrogen limitation developed in the N1 treatment since the beginning of the experiment.
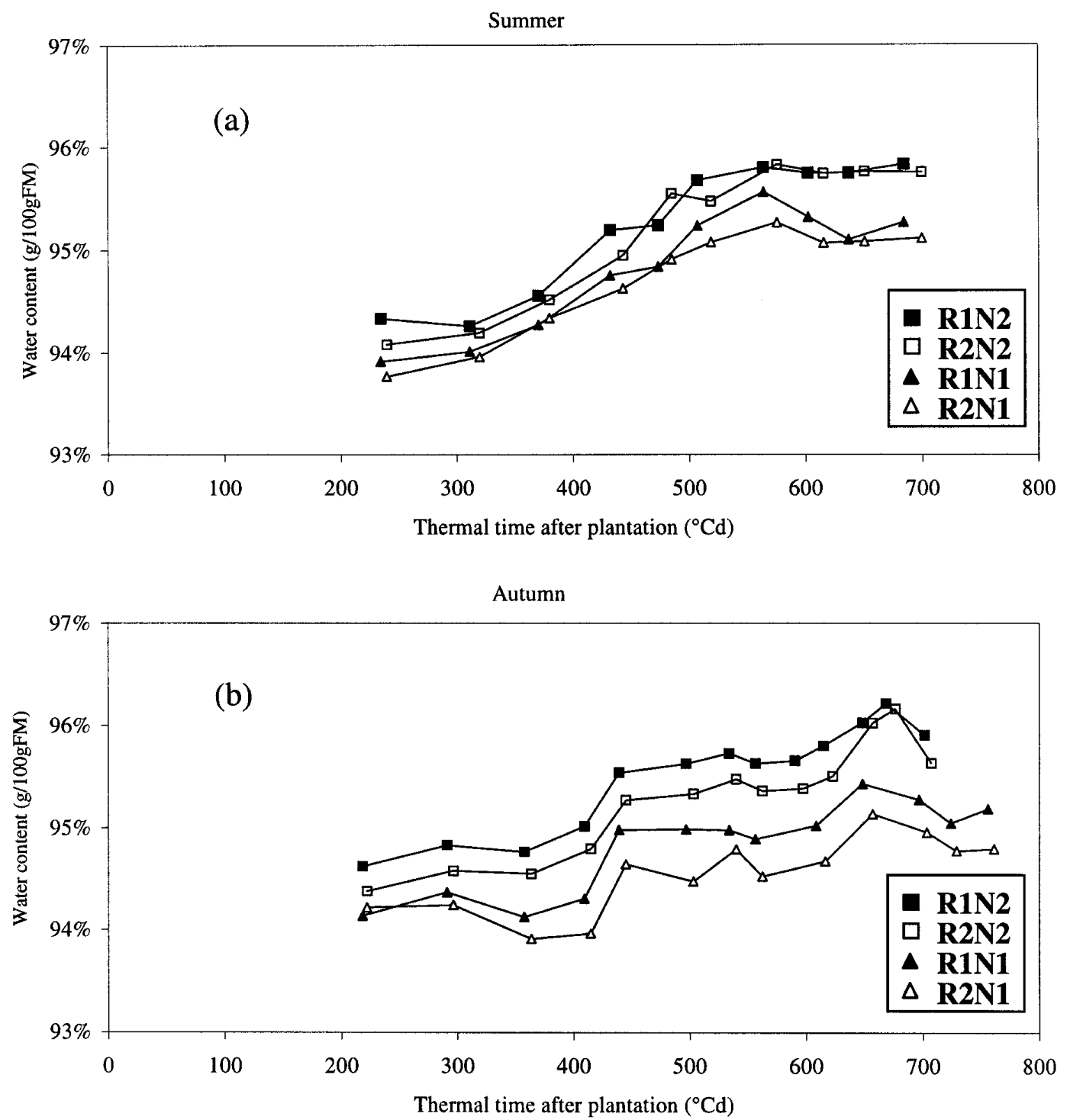

Figure 4. Changes in the water content $\left(\mathrm{g} \mathrm{H}_{2} \mathrm{O} \cdot 100 \mathrm{~g}^{-1}\right.$ fresh matter) of lettuce with thermal time for the summer crop (a) and for the autumn one (b). 


\subsection{Water and nitrate contents}

The change in water content was similar for the two seasons (Fig. 4): it increased until the beginning of heading (500 degree-days after planting), and then remained roughly stable until harvest. The nitrate content remained almost constant throughout the entire summer crop (Fig. 5). It increased at the end of the crop cycle in autumn, in all treatments, presumably due to the lower light intensity at the end of the crop cycle in autumn.

The water and nitrate contents in R1 plants were significantly higher than in R2 throughout the crop cycle in autumn. They were significantly higher in $\mathrm{N} 2$ plants than in N1 throughout the crop cycle for the two seasons. The water and the nitrate contents measured after the heading stage, when the lettuce cover rate became stable, are shown in Figure 6.
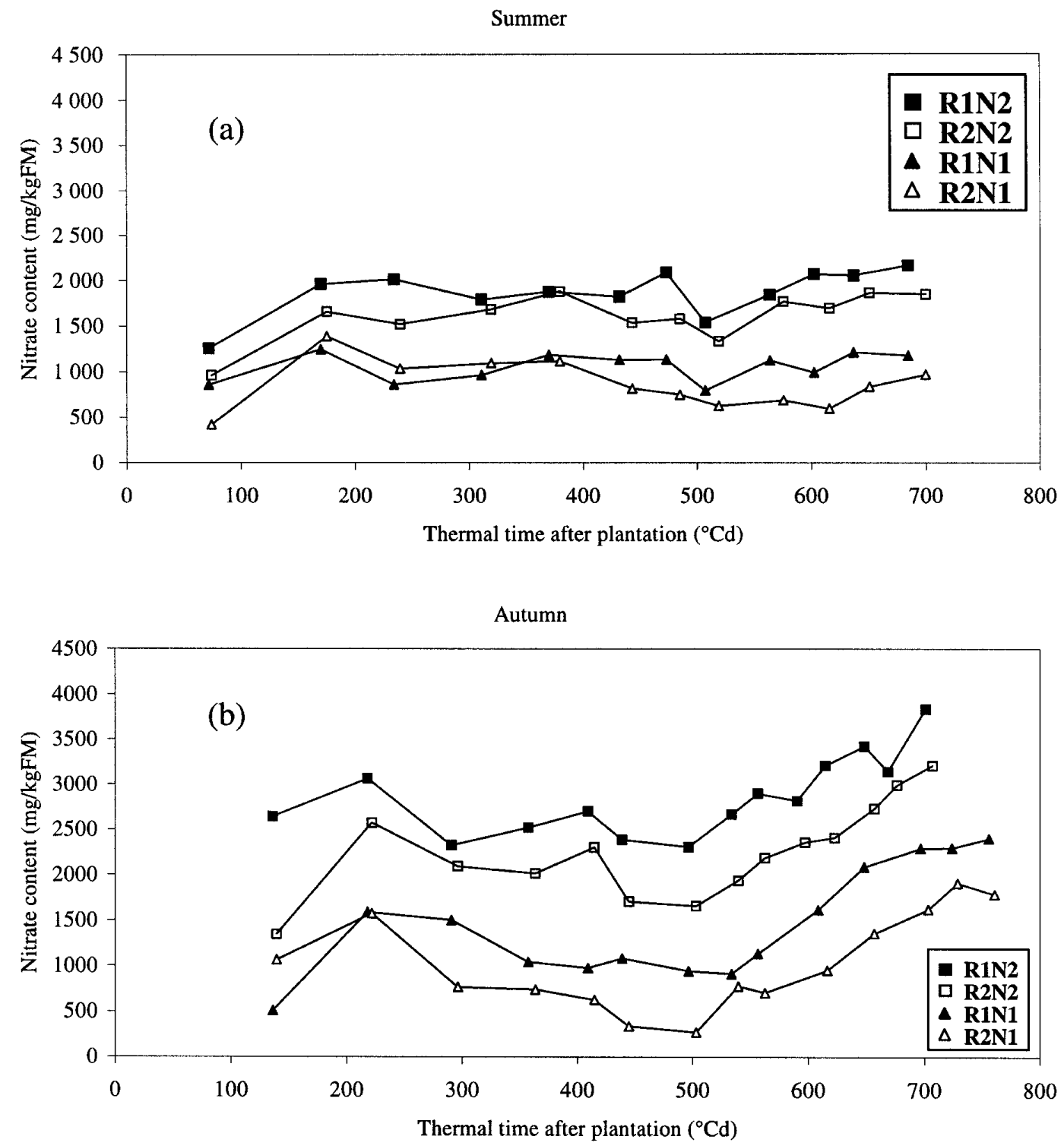

Figure 5. Changes in the nitrate content ( $\mathrm{mg} \mathrm{NO}_{3} \cdot \mathrm{kg}^{-1}$ fresh matter) of lettuce with thermal time in summer (a) and in autumn (b). 

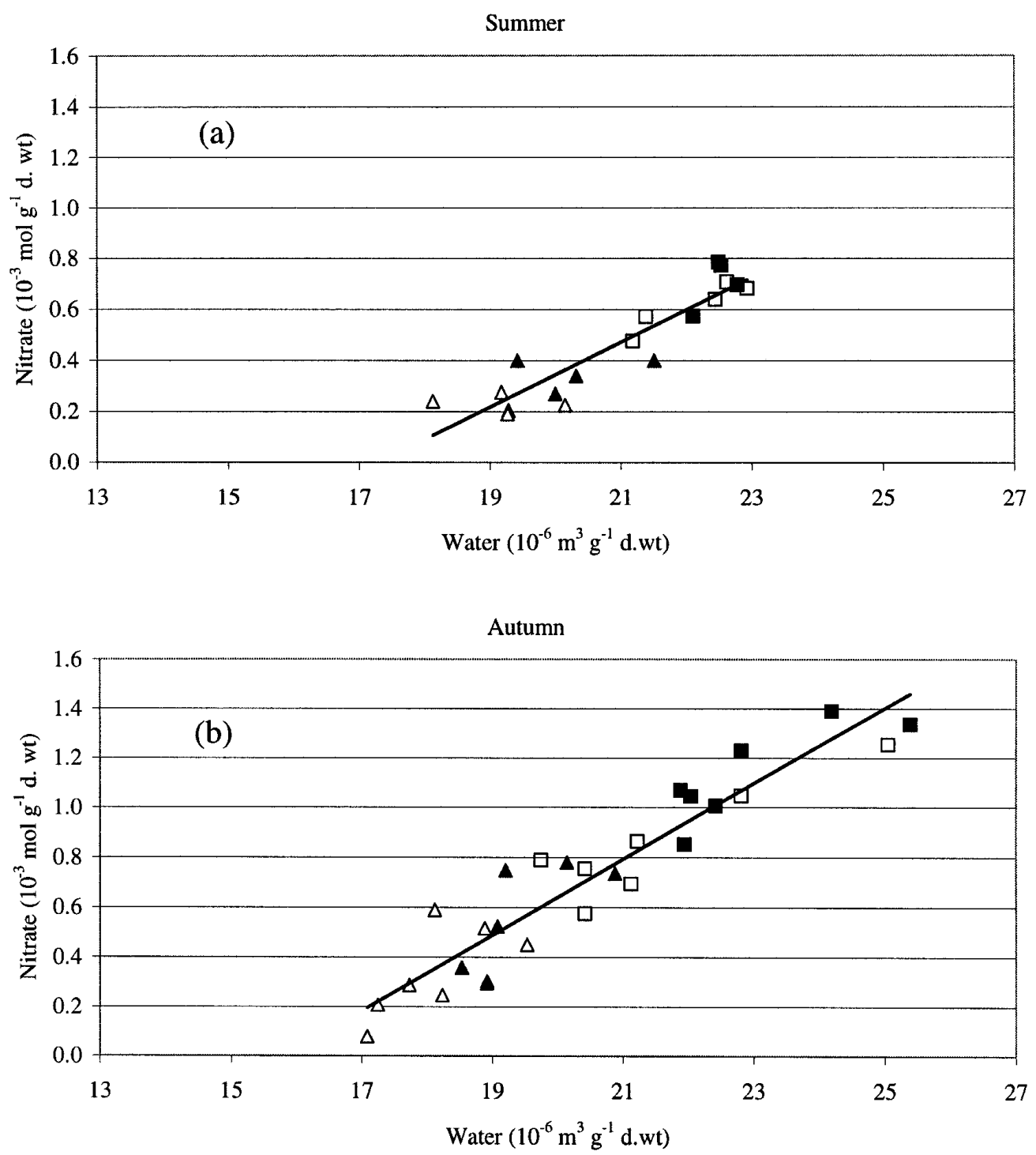

Figure 6. Nitrate content $\left(10^{-3} \mathrm{~mol} \cdot \mathrm{g}^{-1}\right.$ dry matter $)$ of lettuce as a function of their water content $\left(10^{-6} \mathrm{~m}^{3} \cdot \mathrm{g}^{-1} \mathrm{dry}\right.$ matter $)$ in summer (a) and in autumn (b). Same legend as Figure 5.

Units are $\mathrm{mol} \cdot \mathrm{g}^{-1}$ of dry matter for nitrate content and $\mathrm{mm}^{3} \cdot \mathrm{g}^{-1}$ of dry matter for water content so as to compare our results with those obtained by Cárdenas-Navarro et al. [12]. Covariance analysis with water content as a covariant showed that the nitrate content was positively correlated with the water content $\left(\mathrm{F}_{1.45}=113\right)$, with the same slope (Figs. 6a and 6b), but different intercepts, depending on the crop season $\left(\mathrm{F}_{1.45}=77\right)$. This analysis showed no significant effect of nitrogen supply and radiation level on the slope nor on the intercept.

$$
\mathrm{C}_{\mathrm{NO}_{3}^{-}}=138 \times \mathrm{C}_{\mathrm{H}_{2} \mathrm{O}}+\mathrm{a} \quad \mathrm{R}^{2}=0.84
$$

with $\mathrm{a}=-2.18 \times 10^{-3}$ and $-2.41 \times 10^{-3}$ for summer and autumn crops respectively

$\mathrm{C}_{\mathrm{NO}_{3}^{-}}$: nitrate content in dry matter $\left(\mathrm{mol} \cdot \mathrm{g}^{-1}\right)$

$\mathrm{C}_{\mathrm{H}_{2} \mathrm{O}}$ : water content in dry matter $\left(\mathrm{m}^{3} \cdot \mathrm{g}^{-1}\right)$. 


\section{Discussion}

Our results provide information on the effect of climate on lettuce growth via two processes, light interception (linked to changes in cover rate) and conversion of the intercepted radiation into dry matter, and the water and nitrate accumulations by the plant.

\subsection{Cover rate}

For a given plant density, cover rate is essentially influenced by air temperature. The sigmoid relationship between cover rate and thermal time has already been observed $[8,15]$. Although the thermal regimes in autumn and summer were very different (Fig. 1), the cover rate reached a plateau at the same thermal period, $500{ }^{\circ} \mathrm{C} \cdot \mathrm{d}$ after planting for the two seasons, and commercial maturity was reached about $700{ }^{\circ} \mathrm{C} \cdot \mathrm{d}$ after planting. Similar values have been obtained by others for plastic greenhouse spring crops [8] and summer field crops [11].

Radiation and nitrogen supply mainly affected the dynamic of increase in cover rate and its maximum value. The negative effect of radiation on the cover rate is not due to an effect of radiation on Leaf Area Index (LAI): we observed similar evolution of LAI in R1 and R2 treatments (results not shown) even if the Leaf Area Ratio (LAR) increases when the radiation level decreases [22]. The negative effect of radiation on the cover rate can be attributed to an effect of radiation on the relationship between LAI and cover rate: for a given value of LAI, the cover rate was greater in $\mathrm{R} 1$ treatment (results not shown). This suggests that leaf orientation distribution was affected by the radiation level. The effect of nitrogen on the cover rate can be attributed to a decrease of LAI (results not shown) as a result of nitrogen stress [25]. The relationship between LAI and cover rate was not affected by nitrogen supply. Thus, interception efficiency of the PAR by the canopy is affected by the radiation itself and by the nitrogen supply.

\subsection{Accumulation of dry matter}

The nitrogen and radiation supplies, plus the two growing periods, resulted in a wide range of growth conditions for lettuce, with mean values of RUE for dry matter accumulation varying from 2.12 to $3.50 \mathrm{~g} \cdot \mathrm{MJ}^{-1}$. This agrees with some values found in the literature, although it is difficult to compare estimates from different experiments because of the disparity in measurement techniques and in the nature of the observations. Hunt et al. [22] obtained a RUE of 2-4 g. $\mathrm{MJ}^{-1}$, Wheeler et al. [46] found $2.78 \mathrm{~g} \cdot \mathrm{MJ}^{-1}$ for lettuces with 45 leaves; Tei et al. [43] reported a value of $2.43 \mathrm{~g} \cdot \mathrm{MJ}^{-1}$. These latter authors also reported a change in the RUE during lettuce development, with a low value at the beginning of the culture, and an increase at the end of the crop cycle. We found such a change only for the summer crop, where the slope of the relationship between PAR and dry matter increased slightly at the end of the crop cycle (Fig. 3). It is difficult to separate the effects of ontogeny from those of environmental conditions on the RUE, under variable climatic conditions. High temperatures at the beginning of the culture (Fig. 1) could explain the lower RUE values at the early stages of the crop in our experiment. Higher temperatures have been reported to cause a greater respiration, leading to lower RUE [45]. Such an effect of temperature could also explain the values of RUE, which are higher in autumn than in summer.

A major result is the significant effect of radiation level on RUE. The RUE decreased when radiation increased in both trials, in $\mathrm{N} 1$ and in N2. Differences in RUE between R1 and R2 treatments can't be attributed to an effect of temperature since air temperature measured on this experiment was similar in R1 and in R2. This effect of radiation level could be attributed to the fact that the increased radiation put the plants in a state close to the saturation of their photosynthetic capacity, thereby decreasing the efficiency of photosynthesis [22].

The RUE was also higher in N2 than in N1 plants. There may be at least two reasons for this: (i) the shoot/root ratio of the lettuce may have changed, as it is well known that plants grown with 
a poor nitrogen supply have a greater root development [1, 39]. As RUE for nitrogen or biomass accumulation was only evaluated on the aerial parts of the lettuces, it was probably slightly underestimated in the N1 treatment. (ii) Nitrogen shortage is known to decrease leaf photosynthetic efficiency and thus RUE [6, 14, 37].

\subsection{Water and nitrate contents}

The lettuce nitrate and water contents vary greatly even with the same nitrogen supply and radiation level. The positive effect of nitrogen on the plant nitrate content is known [27, 44]. Our experiment, with only two levels of nitrogen, could not ensure that the lettuces reached their maximum nitrate content. The lettuces of the R1N2 batch, in autumn, contained $3800 \mathrm{mg} \mathrm{NO}-\mathrm{kg}^{-1}$ of fresh matter, accounting for up to $40 \%$ of the total nitrogen content (results not shown). Treatment R2N1 limited growth and nitrate content of the lettuces. It is admitted that $\mathrm{N}$ restriction results in greater assimilation of endogenous nitrate [23] which accumulation decreases in consequence, as observed here.

There was a significant positive correlation between the nitrate and water contents. This correlation, first noticed by Maynard et al. [27], could be due to the influence of nitrate on osmotic potential regulation $[9,40]$. It can explain the fact that plants under high nitrogen supply have a higher water content $[24,30]$. We found that the slope of this relationship was not affected by environmental conditions. Cárdenas-Navarro et al. [12], who investigated this relationship for two lettuce cultivars during a day-light cycle in a growth room, and during growth in a glasshouse, confirmed the stability of this slope. They found that the intercept depended on cultivars and experimental conditions (growth room or glasshouse). Our results have led us to a similar conclusion for summer and autumn growth conditions. The lower intercept found in summer compared to autumn is probably caused by the accumulation of soluble carbohydrates in summer when the lettuce plants store more water for a given nitrate content than in autumn.
This link between water and nitrate has been highlighted in several studies on plant physiology. Lettuce plants accumulate nitrate mainly in the outer leaves [2, 13, 21]. Cells in these leaves have large vacuoles [7] where nitrate can be stored. They are also the major site of water accumulation. Reinink and Blom-Zandstra [31] compared lettuce cultivars and showed that the nitrate content increased with the vacuole size. Recent research has shown that the nitrate content of cells influences water absorption [4] and water flow through cells. Nitrate could increase the synthesis of aquaporine in the cell membranes [20]. This information highlights the interdependence of nitrate and water.

Acknowledgements: This work was financed by the French Ministry of Agriculture (DGER). The authors thank the CTIFL for supporting the experiment and the CIRAD-FLHOR (J. Marchal) for the nitrate and total nitrogen analyses.

\section{References}

[1] Ågren G.I., Ingestad T., Root/shoot ratio: a balance between nitrogen productivity and photosynthesis, Plant Cell Environ. 10 (1987) 579-586.

[2] Alt D., Füll A.M., Control of the nitrogen status of lettuce by nitrate analysis of plant sap, Acta Hort. 222 (1988) 23-27.

[3] Andersen L., Nielsen N.E., A new cultivation method for the production of vegetables with low content of nitrate, Sci. Hort. 49 (1992) 167-171.

[4] Barthes L., Bousser A., Hoarau J., Deléens E., Reassesment of the relationship between nitrogen supply and xylem exudation in detopped maize seedlings, Plant Physiol. Biochem. 33 (1995) 173-183.

[5] Behr U., Relation between photosynthesis and nitrate content of lettuce cultivars, Sci. Hortic. 49 (1992) 175-179.

[6] Bélanger G., Gastal F., Lemaire G., Growth analysis of a tall fescue sward fertilized with different rates of nitrogen, Crop Sci. 32 (1992) 1371-1376.

[7] Bensink J., On morphogenesis of lettuce leaves in relation to light and temperature, Meded. Landbouwhogesch. Wageningen 71-15 (1971) 93. 
[8] Bierhuizen J.F., Ebbens J.L., Koomen N.C.A., Effects of temperature and radiation on lettuce growing, Neth. J. Agric. Sci. 21 (1973) 110-116.

[9] Blom-Zandstra M., Lampe J.E.M., The role of nitrate in the osmoregulation of lettuce grown at different light intensities, J. Exp. Bot. 36 (1985) 1043-1052.

[10] Blom-Zandstra M., Lampe J.E.M., Ammerlaan H.M., $\mathrm{C}$ and $\mathrm{N}$ utilisation of two lettuce genotypes during growth under non-varying light conditions and after changing the light intensity, Physiol. Plant. 74 (1988) $147-153$.

[11] Bruno J.F., Papy F., Mieux gérer la sole de laitue dans la vallée de la Seine, Cah. Agric. 1 (1992) 95-100.

[12] Cárdenas-Navarro R., Adamowicz S., Robin P., Nitrate accumulation in plants: a role for water, J. Exp. Bot. 50 (1999) 613-624.

[13] Dapoigny L., Fleury A., Robin P., Relation entre la vitesse relative de croissance et la teneur en azote chez la laitue (Lactuca sativa L.). Effets du rayonnement et de la température, Agronomie 17 (1997) $35-41$.

[14] Dapoigny L., Robin P., Raynal-Lacroix C., Fleury A., Relation entre la vitesse relative de croissance et la teneur en azote chez la laitue (Lactuca sativa L.). Effets de l'ombrage et du niveau de l'alimentation minérale, Agronomie 16 (1996) 529-539.

[15] de Tourdonnet S., Maîtrise de la qualité et de la pollution nitrique en culture de laitues sous abri plastique : diagnostic et modélisation des effets des systèmes de culture, Thèse, Institut National Agronomique Paris-Grignon, Paris, 1998.

[16] Evans J.R., Photosynthesis and nitrogen relationships in leaves of C3 plants, Oecologia 78 (1989) 9-19.

[17] Gaudreau L., Charbonneau J., Vezina L.P., Gosselin A., Effects of photoperiod and photosynthetic photon flux on nitrate content and nitrate reductase activity in greenhouse grown lettuce, J. Plant Nutr. 18 (1995) 437-453.

[18] Gosse G., Varlet-Grancher C., Bonhomme R., Chartier M., Allirand J.M., Production maximale de matière sèche et rayonnement solaire intercepté par un couvert végétal, Agronomie 6 (1986) 47-56.

[19] Gunes A., Post W.N.K., Kirkby E.A., Aktas M., Influence of partial replacement of nitrate by amino acid nitrogen or urea in the nutrient medium on nitrate accumulation in NFT grown winter lettuce, J. Plant Nutr. 17 (1994) 1929-1938.
[20] Hoarau J., Barthes L., Bousser A., Deléens E., Prioul J.L., Effect of nitrate on water transfer across roots of nitrogen pre-starved maize seedlings, Planta 200 (1996) 405-415.

[21] Huett D.O., White E., Determination of critical nitrogen concentrations of lettuce (Lactuca sativa L. cv. Montello) grown in sand culture, Aust. J. Exp. Agric. 32 (1992) 759-764.

[22] Hunt R., Warren Wilson J., Hand D.W., Sweeney D.G., Integrated analysis of growth and light interception in winter lettuce. I- Analytical methods and environmental influences, Ann. Bot. 54 (1984) $743-757$.

[23] Ismande J., Touraine B., N demand and the regulation of nitrate uptake, Plant Physiol. 105 (1994) 1-7.

[24] Leigh R.A., Johnson A.E., Nitrogen concentrations in field-grown spring barley: an examination of the usefulness of expressing concentrations on the basis of tissue water, J. Agric. Sci. 105 (1985) 397-406.

[25] Lemaire G., Salette J., Relation entre dynamique de croissance et dynamique de prélèvement d'azote pour un peuplement de graminées fourragères. I - Étude de l'effet du milieu, Agronomie 4 (1984) 423-430.

[26] Lillo C., Light regulation of nitrate reductase in green leaves of higher plants, Physiol. Plant. 90 (1994) 616-620.

[27] Maynard D.N., Barker A.V., Minotti P.L., Peck N.H., Nitrate accumulation in vegetables, Adv. Agron. 28 (1976) 28-117.

[28] Millard P., The accumulation and storage of nitrogen by herbaceous plants, Plant Cell Environ. 11 (1988) 1-8.

[29] Pontailler J.Y., A cheap quantum sensor using a gallium arsenide photodiode, Funct. Ecol. 4 (1990) 591-596.

[30] Rabin J.W., Parker L., Control of leaf expansion by nitrogen nutrition in sunflower plants: role of hydraulic conductivity and turgor, Plant Physiol. 69 (1982) 771-775.

[31] Reinink K., Blom-Zansdtra M., The relation between cell size, ploidy level and nitrate concentration in lettuce, Physiol. Plant. 76 (1989) 575-580.

[32] Roorda van Eysinga J.P.N.L., Nitrate and glasshouse vegetables, Fertil. Res. 5 (1984) 149-156.

[33] Roorda van Eysinga J.P.N.L., Van der Meijs M.Q., Effect of nitrogen nutrition and global radiation on yield and nitrate content of lettuce grown under glass, Commun. Soil Sci. Plant Anal. 16 (1985) 1293-1300. 
[34] SAS Institute Inc., SAS/STAT users guide, Version 6, Vol. II, 1989, USA: Carry NC.

[35] Scaife A., Cox E.F., Morris G.E.L., The relation between shoot weight, plant density and time during the propagation of four vegetable species, Ann. Bot. 59 (1987) 325-334.

[36] Seginer I., Buwalda F., Van Straten G., Nitrate concentration in greenhouse lettuce: a modelling study, Acta Hort. 456 (1997) 189-197.

[37] Sinclair T.R., Canopy carbon assimilation and crop radiation use efficiency dependance on leaf nitrogen content, in: Boote K.J., Loomis R.S. (Eds.), Modeling crop photosynthesis - from biochemistry to canopy, CSSA Special Publication $n^{\circ} 19$, CSSA, Madison, 1991, pp. 95-106.

[38] Sinclair T.R., Horie T., Leaf nitrogen photosynthesis and crop radiation use efficiency: a review, Crop Sci. 29 (1989) 90-98.

[39] Smolder E., Merkx R., Growth and shoot/root partitionning of spinach plants as affected by nitrogen supply, Plant Cell Environ. 15 (1992) 795-807.

[40] Steingröver E., Siesling J., Ratering P., Effect of one night with low light on uptake, reduction and storage of nitrate in spinach, Physiol. Plant. 66 (1986) $557-562$.

[41] Steingröver E., Steenhuizen J.W., Van Der Boon J., Effects of low light intensities at night on nitrate accumulation in lettuce grown on a recirculating nutrient solution, Neth. J. Agric. Sci. 41 (1993) 13-21.

[42] Stienstra A.W., Does nitrate play a role in osmoregulation?, in: Lambers H. (Ed.), Fundamental, ecological and agriculturical aspects of nitrogen metabolism in higher plants, Dordrecht, Martinus Nijhoff Publ., 1986, pp. 481-484.

[43] Tei F., Scaife A., Aikman D.P., Growth of lettuce, onion and red beet. 1- Growth analysis, light interception and radiation use efficiency, Ann. Bot. 78 (1996) 633-643.

[44] Van Der Boon J., Pieters J.H., Slangen J.H.G., Titulaer H.H.H., The effect of nitrogen fertilization on nitrate accumulation and yield of some fields vegetables, in: Lambers H. (Ed.), Fundamental, ecological and agriculturical aspects of nitrogen metabolism in higher plants, Dordrecht, Martinus Nijhoff Publ., 1986, pp. 489-492.

[45] Wheeler T.R., Hadley P., Ellis R.H., Morison J.I.L., Changes in growth and radiation use by lettuce crops in relation to temperature and ontogeny, Agric. For. Meteorol. 66 (1993) 173-186.

[46] Wheeler T.R., Hadley P., Morison J.I.L., Ellis R.H., Effects of temperature on the growth of lettuce and the implications for assessing the impacts of potential climate change, Eur. J. Agron. 2 (1993) 305-311. 